\title{
Blunt Trauma to the Orbit: A Case for the Use of Ultrasound in the Emergency Department
}

\author{
Julian Birch and Ravi Pattanshetty* \\ Emergency Department, John Radcliffe Hospital, UK
}

Submission: November 28, 2017; Published: December 18, 2017

*Corresponding author: Ravi Pattanshetty, Emergency Department, John Radcliffe Hospital, Oxford, UK, Email: ravipattanshetty@gmail.com

\begin{abstract}
Summary
An elderly lady attended the Emergency Department (ED) in the early hours of the morning with a head injury following a fall from a standing height. She had suffered blunt trauma to her left orbit from her bedside table. Examination revealed multiple lacerations around the eye, with damage to the cornea. A bedside ultrasound showed a ruptured anterior chamber and she was referred to the Ophthalmologists for urgent operative management of globe rupture of the left eye.
\end{abstract}

\section{Case}

An elderly lady attended the A\&E department in the early hours of the morning with a head injury following a fall from a standing height. She had suffered blunt trauma to her left orbit from her bedside table. She appeared unwell, was vomiting, and had significant peri-orbital swelling, however, she reported normal vision and denied pain.

She a past medical history of Type Two Diabetes Mellitus, Ischaemic Heart Disease and Hypertension. She had no known drug allergies and took multiple medications. She lived alone, was independent in her activities of daily living and had a close and supportive family (Figure 1).

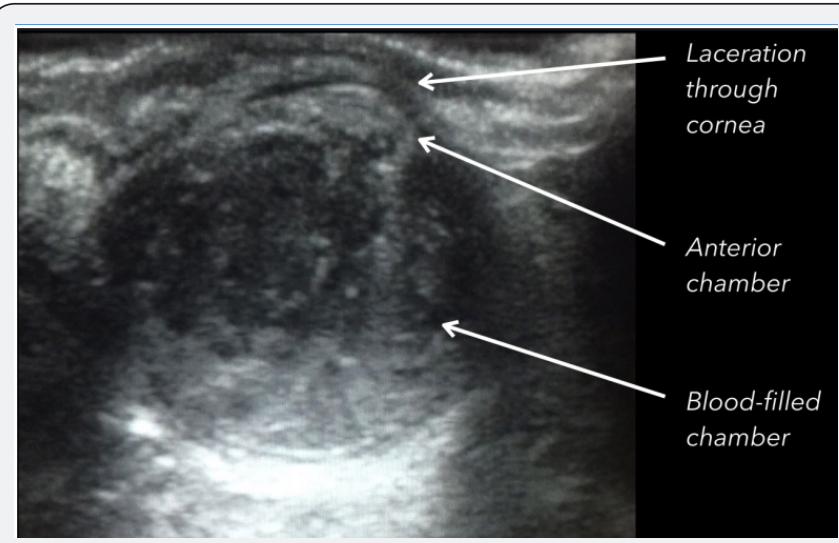

Figure 1

On examination there was a $4 \mathrm{~cm}$ long full-thickness laceration medial to the lacrimal duct. She also had a laceration through the cornea with blood in the anterior chamber (hyphema) and a dilated pupil (traumatic mydriasis) on the left eye. She had normal eye movements and a visual acuity in the right eye was $6 / 7.5$, but perceived hand movements only in the left eye.

At the time of assessment, she had a bedside ultrasound showed a ruptured anterior chamber with a haematoma in the vitreos (see image). She was referred to the Ophthalmologists for urgent management of globe rupture of the left eye. Following the assessment of the Ophthalmologist she also had a CT scan of her head to rule out more significant trauma and to confirm the diagnosis.

In the ED the patient was given analgesia and her wounds were cleaned and dressed loosely with saline-soaked gauze for comfort. She was then transferred to theatre where she underwent

an emergency repair of her left orbit by the Ophthalmology team. This took place within 4 hours of presentation to the Emergency Department.

Post-operatively she was able to perceive hand movements and was discharged home. She was readmitted a few days later due to eye pain and headache. Her Intra-Ocular Pressures were normal in both eyes (12 $\mathrm{mmHg}$ ) but she was dehydrated and was admitted for intravenous fluids and monitoring. She was found to be unable to care for herself, so a care package was arranged and she was discharged home with this in place. She reviewed in the Ophthalmology clinic 1 month later and had no perception of light in the left eye. She has been offered further surgical interventions but has declined and wishes to be managed conservatively due to the risks of further general anaesthesia. 


\section{Learning Points}

a) Ultrasound can diagnose many Ophthalmological pathologies including vitreos haemorrhage and retinal detachment [1].

b) Ultrasound of the orbit is quick and easy to perform in the Emergency Department, with multiple views of the eye structures being easily obtained through a closed eyelid [2].

c) Prompt diagnosis of globe rupture is key, and emergency operative management is the only option to preserve sight [3].

\section{References}

1. Kilker BA, Holst JM, Hoffmann B (2014) Bedside ocular ultrasound in the emergency department. Eur J Emerg Med 21(4): 246-253.

2. Whitson MR, Mayo PH (2016) Ultrasonography in the emergency department. Crit Care 20(1): 227.

3. Grimm LJ (2015) Medscape: Ocular Injury Evaluation using Bedside Ultrasonography. https://emedicine.medscape.com/article/1401982overview

\section{Your next submission with Juniper Publishers} will reach you the below assets

- Quality Editorial service

- Swift Peer Review

- Reprints availability

- E-prints Service

- Manuscript Podcast for convenient understanding

- Global attainment for your research

- Manuscript accessibility in different formats

( Pdf, E-pub, Full Text, Audio)

- Unceasing customer service

Track the below URL for one-step submission https://juniperpublishers.com/online-submission.php 